\title{
Transforming conflicts from the bottom-up? Reflections on civil society efforts to empower marginalized fishers in postwar Sri Lanka
}

\author{
Joeri Scholtens $^{1}$ and Maarten Bavinck ${ }^{1,2}$
}

\begin{abstract}
We analyze the efforts of an international consortium of academics and activists to understand and address a transnational fisheries conflict in South Asia. The so-called REINCORPFISH project (2010-2016) focused on an asymmetrical conflict between trawler fishers from the Indian state of Tamil Nadu who frequently transgress into Sri Lankan waters and northern Sri Lankan fishers, whose livelihoods are affected by these intrusions as well as by a long history of civil war. Guided by notions of bottom-up governance and empowerment, the consortium engaged in action research focusing on three types of remedial activities: (a) facilitating dialogues between fishers from both countries, (b) supporting the creation of a unified fisher organization in northern Sri Lanka, and (c) engaging in an advocacy program promoting assistance for the northern Sri Lankan fishers. Although the consortium succeeded in creating widespread attention of the problem, we analyze how the project's rationale of bottom-up governance was thoroughly challenged by divisive national and transboundary politics. The fisheries conflict intertwined with geopolitical power play, military bluster, and ethnic tension, as well as with governmental suspicion toward NGO activity of any kind, marginalized civil society and compromised its assumed role as an agent of change. We therefore demonstrate how supporting marginalized resource users through action research requires handling a multiplicity of coexisting conflicts (resource, ethnic, and geopolitical) and that studying or dealing with such conflicts in isolation is both conceptually and practically flawed.
\end{abstract}

Key Words: action research; bottom-up governance; empowerment; fisheries; marginality; postwar reconstruction; Sri Lanka; transboundary conflict

\section{INTRODUCTION}

Development studies entail the analysis of social change as well as the pursuit of directed progress. In a stereotypical way, the first is the domain of the scientist who critically describes and reflects; the second is the domain of the practitioner, who is in possession of forward-looking, professional optimism (Lund 2010). These two domains, however, do not operate in isolation; they are conceptually and empirically blurred and influenced by each other.

In the spirit of overcoming the presumed duality of science and practice and facilitating transdisciplinary engagement with conflicts over natural resources, the Netherlands Organisation for Scientific Research (NWO), together with the Netherlands Ministry of Foreign Affairs, funded an innovative program that was geared toward addressing conflict and cooperation over natural resources $(\mathrm{CoCooN})$ in various parts of the world (Frerks et al. 2014). As part of this program, it happened that one year after the end of the Sri Lankan civil war (2009), a consortium of Dutch, Indian, and Sri Lankan universities and NGOs, including the two authors of this paper, commenced an action research project with the acronym REINCORPFISH.

This research-cum-action project aimed to understand and address a protracted transboundary fishing conflict in the Palk Bay, which is a secluded marine area of approximately $12,000 \mathrm{~km}^{2}$ between India and Sri Lanka. Trawl fishers from the Indian state of Tamil Nadu were illegally frequenting northern Sri Lankan fishing grounds in large numbers, and by doing so, compromised the fishing opportunities for a large population of Sri Lankan small-scale fishers, preventing their recovery from the effects of the brutal civil war.

The consortium's objective was to address this transboundary resource conflict by working from the bottom-up on both sides of the Palk Bay and thereby to "facilitate the development and implementation of a new framework for the regulation of fisheries" (REINCORPFISH 2010, unpublished report). On the Sri Lankan side, the consortium strove to advance its objective by empowering northern Sri Lankan fishers in their interactions with Indian fishers as well as with the Sri Lankan authorities. The central purpose of this article is to understand and reflect on the challenges of this international civil society-based initiative to transform a transboundary fishing conflict from the bottom-up. Theoretically, we draw on literature concerning bottom-up governance, empowerment, and civic-driven change (Fowler and Biekart 2013). Our focus is on the process as it unfolded on the Sri Lankan side of the Bay, largely leaving aside its accomplishments in India, which have been discussed elsewhere (Stephen 2015, Menon et al. 2016). This article thus makes a contribution as a piece of action research in the context of postwar construction, teasing out conceptual and practical insights by reflecting on the challenges encountered by the transdisciplinary consortium of NGOs and academics aiming to transform the fisheries conflict.

\section{THEORETICAL INROADS}

The following conceptualizations of empowerment, bottom-up governance and civil society serve a twin purpose. First, they provide a conceptual background to the rationale of the project's interventions; second, they offer material for reflection on some of the project's accomplishments and challenges. In this sense, we position ourselves as project holders while simultaneously claiming a capacity to reflect on the project as relative outsiders.

\section{Bottom-up governance and empowerment}

Following disappointment with decades of state-based, top-down models of fisheries management, as well as increasing concerns over declining fish stocks and crises of institutional legitimacy, 
an extensive body of knowledge on fisheries governance has emerged since the 1980s. The resulting conceptualization of governance has both analytical and normative dimensions: "[G] overnance is both what is and what should be, both reality and potential" (Kooiman and Bavinck 2005:16). Analytically, governance proceeds from the observation that a plethora of actors other than the state takes part in steering society (Kooiman et al. 2005). Normatively, the concept suggests that "the solution to many present day challenges does not rest with government alone but must also involve other sectors of society" (Chuenpagdee and Jentoft 2009:111) and proposes a view "of governance as a space of interaction, collaboration, deliberation and problem solving" (Sowman and Wynberg 2014:8).

The governance paradigm has inspired the promotion of new fisheries management models, suggesting the active involvement of user groups in the formulation, implementation, and monitoring of institutions. The underlying rationale is that involving users in the formulation and implementation of regulations enhances the probability of their legitimacy, fairness, compliance, and hence effectiveness (Jentoft 2004). Such thinking has spurred the promotion of approaches with resounding titles such as self-governance (Kooiman et al. 2005), community-based governance (Ostrom 1990), participatory governance (Gray 2005), comanagement (Pomeroy and Berkes 1997, Jentoft 1989), and bottom-up governance (Christie and White 2007, van Ginkel 2009). For the latter concept, which was the starting point of the project, we use the generic definition by Rosenau and Czempiel (1992:82): "Bottom up governance refers to policies that may be ratified by governments but that are propelled and unfold mainly outside the halls of government."

The notion of governance has faced ample criticism, amongst others, for blurring the descriptive and the prescriptive and for downplaying the power politics inherent in resource allocation processes (Torfing et al. 2012, Scholtens 2016a). First, the focus on the range of normative principles embedded in governance has been criticized from the perspective that it becomes too much like a recipe (Armitage 2007), leading to potential slippage from understanding how governance works to normatively judging how well it works (Mwangi and Wardell 2012). Second, the emphasis on collaboration between state and nonstate actors suggests that the state performs in a "morally and socially positive manner" as a "benevolent patron of the public interest" (Davis and Ruddle 2012:244). Davis and Ruddle (2012) go as far as to suggest that notions of comanagement and participatory governance constitute a "betrayal of small-scale fishers" for its naïve endorsement of neoliberal state policies and for its neglect of power abuse, wealth appropriation, and exploitation (Davis and Ruddle 2012). Despite these critiques, there has been a strong conviction among fisheries governance scholars that participatory and collaborative forms of governance allow for the alleviation of marginality and are instrumental in addressing procedural injustices and empowering peripheral parties and voices (Jentoft 2005, 2007).

Because bottom-up governance assumes a certain capacity among resource users and, where this capacity is lacking, promotes its improvement, it is useful to examine the notion of empowerment, with which capacity is often associated. Ideas of empowerment lie at the heart of the alternative development paradigm (Friedmann 1992). Empowerment can be understood as a process or an outcome and as either a goal in itself or rather valued instrumentally for achieving other ends (Jentoft 2005). In this article, we understand empowerment as a process of increasing capacities for achieving resource access, with access defined as the ability to benefit from resources (Ribot and Peluso 2003). Improving resource access vis-à-vis others can occur through changing rules and regulations, improving technology, or realizing access to authorities or other elites (Ribot and Peluso 2003).

To understand the nature of empowerment, Mohan and Stokke (2000) make a useful distinction between revisionist neoliberal and post-Marxist approaches. From the first perspective, empowerment entails a harmonious process of building bottomup, organizational structures through multistakeholder deliberations. Here, empowerment has win-win potential, with the assumption that bringing about positive change for marginal groups can take place within existing power structures (Mohan and Stokke 2000). The second perspective understands empowerment as mobilization that challenges hegemonic interests within the state and the market (Mohan and Stokke 2000). From this perspective, empowerment is a conflictive and potentially zero-sum game that cannot occur without disempowerment; "those who are being empowered are doing so at someone's expense" (Jentoft 2005:2). This perspective stresses that marginalization is produced by adverse socio-political interactions and that empowerment is, therefore, a relational phenomenon.

In terms of empowering resource users for gaining resource access, the difference between these two approaches is significant. A harmonious approach to empowerment may build institutional capacity, negotiate collective outcomes with competing resource users, and generate capacity for potential lobbying. A confrontational approach may instead entail collective mobilization for public protest, confronting exclusion, and challenging rights and discourses that privilege dominant resource users (Fowler and Biekart 2013).

\section{Civil society as an agent of change}

Processes of bottom-up governance and empowerment assume notable roles for grassroots groups, NGOs, and other nonstate actors. In the lexicon of international development, civil society has been used both to describe an array of nonstate actors acting as efficient "agent[s] for a participatory and empowering form of development," where the state does not deliver, but also as representing the "bases of a counter-hegemonic bloc of social forces engaged in a process of contesting the state" (Veltmeyer 2009:222). In this paper, we use the term civil society primarily to refer to the consortium of local and foreign universities and NGOs that was expected to play a joint role in transforming the Palk Bay conflict while also broadening the term to include fishers' organizations, the media, and the clergy.

What then was presumed to be the role of civil society in empowering marginalized groups, in this case, northern Sri Lankan fishers, for obtaining access to natural resources? Kelleher and Taulbee (2017) provide a useful entry point, arguing that, in the context of transboundary conflicts, a strong civil society potentially allows for facilitating creative and informal "track II" diplomacy that cuts through the red tape of conventional interstate diplomacy, i.e., track I. 
Track II offers a 'bottom up' ... approach in contrast to the top down, mediated solutions often touted in the past. In this process, NGOs who have become deeply embedded in societies can act as facilitators and conduits, that is as agents who make productive exchange among players possible and who provide 'ground truth' to governments and other interested parties. (Kelleher and Taulbee 2017:83)

This approach seems to fit in the aforementioned revisionist approach.

Fowler and Biekart (2013) provide a more critical understanding of civil society in their work on civic driven change (CDC). Civic driven change entails citizen-driven approaches to social problem solving and has a strong bottom-up orientation. To this end, the authors propose empowerment through civic agency as a tool for targeting disempowering structures. Fowler and Biekart (2013) contend that the present civil society discourse has become too depoliticized to provide a framework for meaningful change. According to them, development cooperation as "currently envisaged and applied is too seldom able to support endogenous civic agency without undermining it"; development practices, therefore, require "a better and more honest appreciation of power and the limited role of outsiders" (Fowler and Biekart 2011:27). In this perspective, processes of change are not always harmonious, and civic resistance is required to challenge authority holders.

Another critique of civil society-led interventions concerns the limitations imposed by postwar and authoritarian contexts. In repressive regimes, critical civil society organizations operating outside patronage systems of the state need to be well networked to deal with the risk involved (Loveman 1998). At a more fundamental level, Paris (2004), in a critical account of international peacebuilding interventions, warns of the potentially damaging and destabilizing effects of promoting participatory forms of governance in war-torn societies in the absence of well-established domestic institutions.

In sum, in the conceptualization of bottom-up governance, empowerment, and the role of civil society, there are strains between the institutionalist perspective focusing on building more inclusive collaboration processes and a more radical perspective emphasizing the primacy of the political. We will demonstrate how these strains are not merely theoretical but may actually be encountered in practice.

\section{POLITICAL CONTOURS OF THE NORTHERN SRI LANKAN FISHERS' STRUGGLE}

\section{Sri Lanka's postwar anxieties}

In May 2009, Sri Lanka's armed forces' victory over the Liberation Tigers of Tamil Eezham (LTTE) marked an uncertain end to three decades of brutal civil warfare. The civil war between Sri Lanka's armed forces, answering to a Sinhalese-dominated state, and the separatist Tamil guerrilla movement LTTE, caused hundreds of thousands of casualties and massive disruption, especially of Sri Lanka's Northern Province, which borders the Palk Bay. Although the victory of government forces in 2009 provided hopes for the possibility of reconciliation, the first postwar period, which terminated with the election of a new president in January 2015, is described as one of "oppressive stability" (Wickramasinghe 2014). The ruling coalition, capitalizing electorally on the war victory, established a nepotistic state characterized by chauvinist family rule. The military gained a new role of safeguarding regime interests and controlling public institutions, resulting in a culture of fear and impunity, in particular in Tamil-majority areas (David 2013, Kumar 2013). Meanwhile, a neoliberal growth and development agenda, financed mostly through Chinese loans, resulted in the significant physical reconstruction of war-affected regions. However, the rural economy and associated livelihoods hardly received any attention, leading to further economic marginalization and indebtedness of an already war-traumatized population in northern Sri Lanka (Kadirgamar 2013). Meanwhile, the tone of postwar, nationalist Tamil politics suppressed the possibility of public deliberation on the violent history of the LTTE and the day-to-day socioeconomic struggles of Tamils throughout the war (Hoole and Arulingam 2015).

The postwar accusations of war crimes generated a powerful UNHRC-led human rights investigation, which called upon the Sri Lankan government to initiate a thorough investigation and reconciliation process. The Sri Lankan government, however, responded defensively to what it argued to be an intrusive and hypocritical Western human rights agenda that interfered with Sri Lankan sovereign affairs. In the process, local and international NGOs in Sri Lanka received threats, counterallegations, and public embarrassments. According to Wickramasinghe (2014:408), this period was, for NGOs and citizens, a time of "total compliance or desperate revolt."

On the other side of the Palk Bay, in the neighboring Indian state of Tamil Nadu, anti-Sri Lanka rhetoric had become an important constituent of daily politics. In 2011, the Tamil Nadu Assembly even adopted a resolution declaring Sri Lanka to be an enemy state (Scholtens et al. 2013). The Central Government of India, which had a history of interference in Sri Lankan affairs (including military intervention from 1987 to 1990), pressured Sri Lanka to implement a political devolution program and voted twice in support of the UNHRC resolution against Sri Lanka. It is in this charged political context that the struggle of northern Sri Lankan fishers needs to be interpreted.

\section{Layers of northern Sri Lankan fishers' marginality}

By 2014, in Sri Lanka's Northern Province, 40,000 fishers were operating approximately 12,000 small-scale fishing craft (three to six meters) in combination with a wide range of passive gear, such as gills nets and drift nets (MFARD 2015). Fishing in this region has traditionally been a caste-based occupation and is one of the major sources of livelihood, with an estimated $25 \%$ of the population of the Northern Province being dependent on the sector (for a detailed account of northern Sri Lankan fisheries, see Scholtens 2016a). The current predicament of the fishing population is the result of multiple interlinked processes of marginalization.

During much of the civil war, fishing in northern Sri Lanka was restricted by security forces in order to prevent LTTE guerrillas from launching attacks from fishing boats (Scholtens 2016b). Many fishing households were displaced multiple times, fleeing from the continuously shifting frontlines. Postwar, after restrictions were lifted and the small-scale fleet was partially rebuilt, fishing had been severely compromised by a sizeable 
Indian trawl fleet that made use of the vacuum in Sri Lankan waters to illegally frequent these rich fishing grounds (Fig. 1). The Indian fleet consisted of approximately 1500 mid-size trawlers with relatively powerful engines $(<192 \mathrm{hp})$ that completely outsized the Sri Lankan craft. Sri Lankan fishers, operating small craft and making use of passive fishing gear, had to avoid the trawlers lest they run the risk of severely damaging their nets. The trawler intrusions, therefore, resulted in not only harm to the natural habitat but also damaged fishing gear, many days of nonfishing, reduced incomes, and increased indebtedness (Scholtens et al. 2012).

Fig. 1. Annual observations and arrests of Tamil Nadu trawlers in Sri Lankan waters (Source: Sri Lankan Navy 2016, unpublished data).

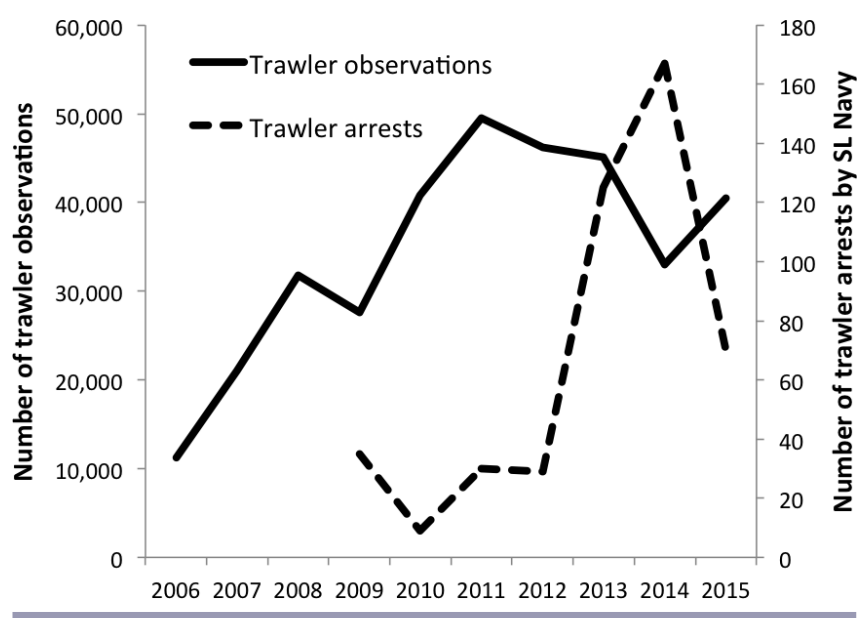

Prior to the start of the civil war, the Indo-Sri Lankan International Maritime Boundary Line had been successfully negotiated, with the bilateral agreements of 1974 and 1976 and a subsequent exchange of letters between both governments stipulating that both countries have exclusive fishing rights on their respective sides of the boundary (Suryanarayan 2005, Chandrahasan 2014). Despite the evident illegality of crossboundary trawl operations, the Sri Lankan Navy's rate of arresting Indian trawl fishers was remarkably low (see Fig. 1). These Indian fishers had significant political support in Tamil $\mathrm{Nadu}$, where politicians were eager to take up the plight of "their fishers" in order to capitalize on anti-Sinhala sentiments in their constituencies (Scholtens et al. 2013). Hence, whenever the Sri Lankan Navy arrested Indian trawl fishers, Tamil Nadu politicians framed these arrests as a continuation of Sinhalese violence against Tamils. Such arrests usually resulted in political drama in which the Sri Lankan government eventually bowed to Indian pressure, leading to the early release of the detained Indian boats and fishers (Scholtens and Bavinck 2014). Because of the limited political influence of northern Sri Lankan fishers, arrests and releases of Indian fishers were also occasionally employed by the Sri Lankan government as a pawn in its broader negotiations with India. This political imbalance, which constitutes the second layer of marginality, limited the Sri Lankan Navy to take more decisive action against boundary transgressions.

The third layer of marginality consisted of the fact that the principal Tamil political party in Sri Lanka (the Tamil National
Alliance, or TNA) was reluctant to take on the cause of its fisher constituency. One reason for this reluctance is the TNA's historical bias toward the Tamil land-owning caste (Kuganathan 2014). In addition, the TNA seemed to believe that it required support from "big brother" Tamil Nadu to achieve its objectives of political devolution in Sri Lanka. Two local observers captured the resulting orphaning of northern Sri Lankan fishers, as follows:

The criminal nature of the Indian trawler enterprise and
the severe damages that it unleashed upon the resettled
northern Tamil fishing communities somehow escaped
Tamil nationalist attention-both here and abroad. While
the Indian fishers successfully lobbied the Tamil Nadu
and the central Indian governments to their aid, our
fishers were bereft of political agency as both the Tamil
leadership and the Sri Lankan government evaded
confrontation. (Hoole and Arulingam 2015:74)

Tamil Sri Lankan fishers were thus unable to assert their rights over adjacent waters because of a combination of technological and political marginality. It was against this background that the REINCORPFISH project commenced.

\section{THE MAKING OF THE REINCORPFISH PROJECT}

\section{Actors, roles, and relations}

The REINCORPFISH project was initiated in 2010 by the second author of this paper, in collaboration with like-minded academics and activists in India and Sri Lanka, with the first author participating in the project as a $\mathrm{PhD}$ candidate. All participants had a history of research or activism in South Asia's fisheries sector. The project built on earlier collaborations and also created new linkages across Sri Lankan ethnic identities (Tamil and Sinhala), countries (Sri Lanka, India, and the Netherlands), civil society sectors (NGOs, universities, and the media), and academic disciplines (marine ecologists, economists, geographers, and anthropologists).

On the Sri Lankan side of the project, the consortium included a university in the Sinhala-dominated south and another in the Tamil-dominated north, a Sri Lankan NGO for which we use the pseudonym Sri Lankan Fishers Unity (SLFU), an Indian NGO with a long history of engaging with the transboundary conflict, an Indian university, and the University of Amsterdam. The SLFU's primary role was to pursue the project's action agenda in Sri Lanka. The SLFU had a history of fisher mobilization across the country and pursued a rights-based approach. It enjoyed considerable legitimacy among northern fishers, not in the least for its successful island-wide mobilization of fishers during the ceasefire period (2002-2006) to lobby for the removal of the harsh fishing restrictions. The SLFU derived its funds from various, mostly Western, donors and is closely connected with other rightsbased NGOs in the country. The Indian NGO liaised with the SLFU and with the other partners to develop an appropriate cross-country strategy. The Sri Lankan university partners undertook parts of the research of REINCORPFISH, hosted meetings and conferences on the fisheries struggle, and occasionally joined the SLFU in its advocacy activities. Later on, the consortium also developed links with local activists and journalists who helped develop a media strategy.

The University of Amsterdam team comprised the authors of this paper. The second author has a long history of studying 
Table 1. Project activities and their rationales.

\begin{tabular}{|c|c|c|}
\hline Project activities & What & Rationale \\
\hline Transboundary fisher to fisher dialogues & $\begin{array}{l}\text { Facilitate negotiation through dialogues between } \\
\text { fisher groups from Tamil Nadu and Sri Lanka. }\end{array}$ & $\begin{array}{l}\text { Build on commonality of (Tamil) fisher groups } \\
\text { in Sri Lanka and India and facilitate process of } \\
\text { bottom-up governance of the transboundary } \\
\text { fishing space. }\end{array}$ \\
\hline Organizing fisher leaders & $\begin{array}{l}\text { Bring fisher leaders from different northern Sri } \\
\text { Lankan districts together in one "Alliance." }\end{array}$ & $\begin{array}{l}\text { Building collective intentionality among fishers is } \\
\text { crucial for raising their profile and to engage in } \\
\text { public action. }\end{array}$ \\
\hline Gaining government buy-in & $\begin{array}{l}\text { Inform, assist, and collaborate with government } \\
\text { in the development of a governance framework } \\
\text { and the resolution of fisher conflicts. }\end{array}$ & $\begin{array}{l}\text { The Palk Bay fishing conflict cannot be resolved } \\
\text { without the commitment of both governments. }\end{array}$ \\
\hline Advocacy for fishing rights & $\begin{array}{l}\text { Organizing conference, stakeholder meetings, } \\
\text { engaging media, and sensitizing Tamil and } \\
\text { Sinhala authorities. }\end{array}$ & $\begin{array}{l}\text { Put the fisheries conflict, and the struggle of } \\
\text { north Sri Lankan fishers therein, higher on the } \\
\text { societal and political agenda. }\end{array}$ \\
\hline
\end{tabular}

Indian and Sri Lankan fisheries (e.g., Bavinck 2001, Bavinck 2005). As the project coordinator, he was responsible for adjusting plans and keeping the project on an even keel. The first author conducted 13 months of mixed methods fieldwork from 2011 to 2013, primarily in Jaffna District, which included three sets of activities with relevance to this paper. First, by spending one month in each of the three selected villages, he studied the impacts of the Indian trawler activities and the functioning of local fisher organizations. Second, he engaged extensively with the village and district fisher leaders ( 83 open interviews), joining their meetings at the village, district, and national levels whenever possible (16 district and national meetings). Finally, he regularly interacted with the SLFU by joining their meetings with fisher leaders. The first author thus had a double role of conducting research while simultaneously participating in the project's action agenda. This double role entailed a balancing act inherent in action research. In order to maintain impartial opportunity to discuss the project with fisher leaders, he tried to maintain some distance from the SLFU, for example, by avoiding taking on the role of intermediary between fisher leaders and the SLFU.

In the given geopolitical and postwar context, the positionality of the two authors as white Europeans was also not trivial, and implied being typically subjected to framings like "the NGO man potentially bringing in resources," or the "human rights activist focused on revealing war crimes to the international community." Both views obviously influenced our access to fishers and authorities and generated various suspicions, thus requiring continuous explanations of our positions and interests.

\section{REINCORPFISH rationale}

Although the consortium partners had diverse backgrounds, motives, and aspirations, they shared two points of departure. First, the governance of the Palk Bay fisheries was in a crisis, and an effective and fair governance and conflict transformation process could only be achieved through the active involvement of fishers from both sides. Second, after decades of war, northern Sri Lankan fishers occupied marginal positions vis-à-vis Tamil Nadu trawler fishers and their respective governments and because of the asymmetrical nature of the prevailing conflict, they required special support. The project imperative was, therefore, "to develop a common governance framework between parties ... confirming the rights and responsibilities of small-scale fishing populations" (REINCORPFISH 2010, unpublished report).
Although the Indian partners in REINCORPFISH focused on understanding the logic of transboundary trawl fishing and ultimately bringing this sector under control, the Sri Lankan partners concentrated on promoting the collective agency of small-scale fishers in the Northern Province. Over the course of its five-year duration, in addition to supportive research, the project engaged in four types of activity (see Table 1 and Fig. 2).

\section{THE PROJECT IN PRACTICE: RATIONALE CONFRONTED}

\section{Indo-Sri Lankan fisher dialogues}

It was assumed that, because Tamil Nadu and northern Sri Lankan fishers share a language, a profession, and an ethnopolitical identity, there would be fertile ground for dialogue. Finding its feet in the postwar setting, REINCORPFISH, by means of the SLFU and the Indian NGO, supported a new set of dialogue meetings that occurred in 2010 (Stephen et al. 2013), an initiative that was met with cautious support from both governments. On this occasion, the two groups of fishers reached what looked like a promising agreement, stipulating that Indian trawl fishers would terminate trawling after one year; during the transition period, trawlers would be allowed to continue fishing in a limited section of Sri Lankan waters for a total of 70 days (see Stephen et al. 2013 for details). The REINCORPFISH consortium viewed the 2010 dialogue as an upbeat start to the project.

The Sri Lankan government, however, soon made it known that it had not been "appraised of the proposals that have been agreed upon by two fishing communities [...] during the Chennai meeting" and subsequently started to oppose the dialogue process. The government accused the SLFU of hand-picking LTTEaffiliated fisher delegates to suit its own political needs and of buying into the logic of "sharing waters" with India, thus undermining Sri Lanka's territorial integrity. Fisher leaders in northern Sri Lanka subsequently reported that they were warned to no longer deal with the SLFU, and the Ministry of Fisheries announced that, because the transboundary fishing conflict was an issue for the two governments to solve, there would be no more bilateral fisher dialogues and no role for third party involvement.

The ferocity of the governmental backlash had several causes. First, during the dialogue visit to Tamil Nadu, some Tamil Sri Lankan delegates capitalized on the presence of an eager Tamil 
Fig. 2. REINCORPFISH's suggested pathways to facilitate transformation in the Palk Bay fisheries conflict.

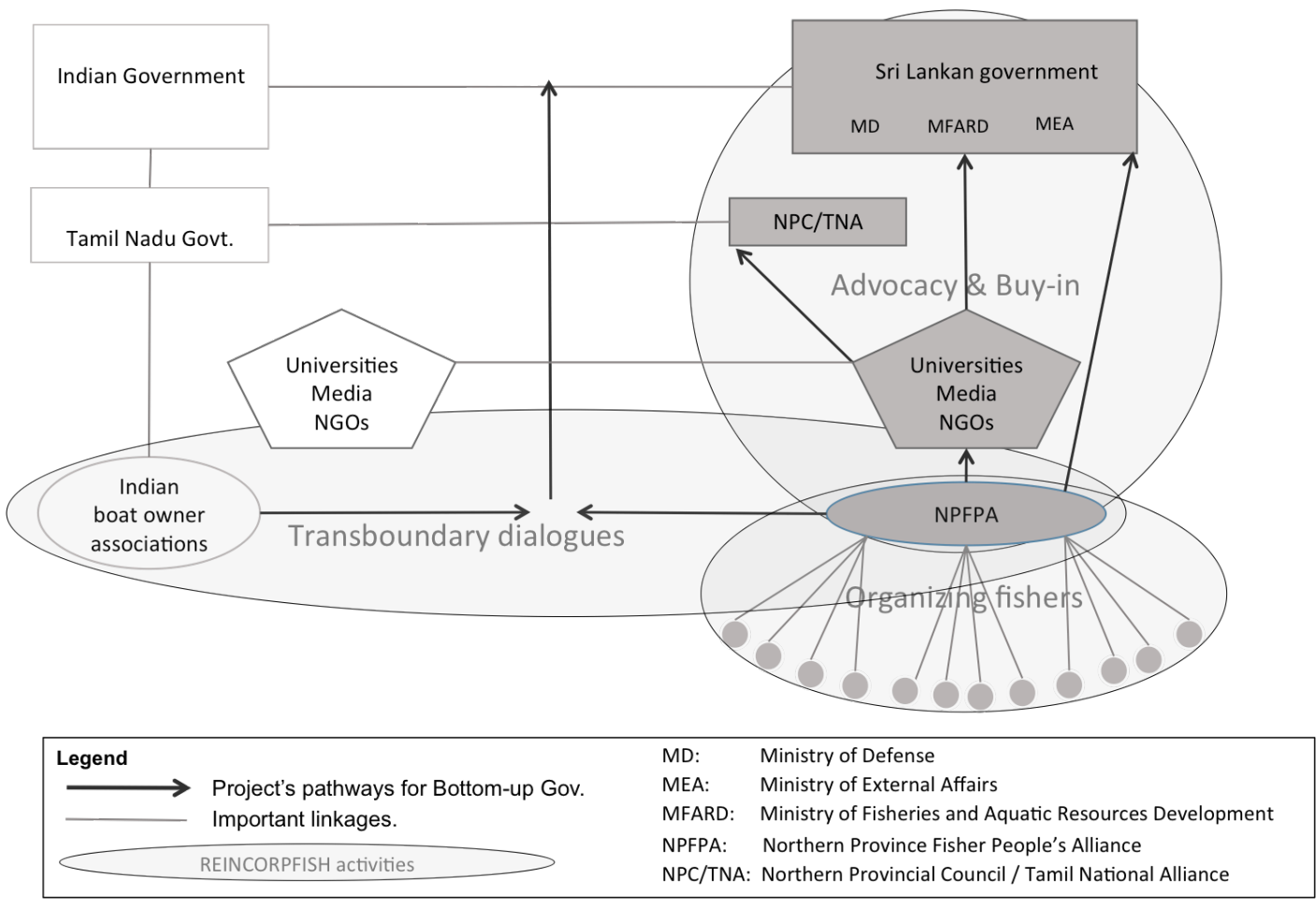

audience to criticize the Sri Lankan government. Second, the backlash reflected a larger tension between Sri Lankan authorities and rights-based NGOs in Sri Lanka, among which is the SLFU, who was considered a major "troublemaker." Third, while the dialogue organizers mostly viewed the issue from a livelihood and fisheries management perspective, for the Sri Lankan government, sovereignty and security were the primary framings. In short, the promising transboundary dialogues had inadvertently flamed a range of state anxieties.

Ironically, because of the continuing stalemate over the fisheries conflict in the following years, both governments started to take their own initiatives for subsequent rounds of fisher dialogue. In 2011, the Sri Lankan government hosted a meeting between fishers from both sides, which was primarily used to reprimand Tamil Nadu trawler owners, and left no scope for negotiation. The political establishment in Tamil Nadu subsequently blocked any further fisher dialogues, from which it felt that it had little to gain (Sathya Moorthy 2013). When the Sri Lankan government significantly increased the number and duration of trawler arrests in 2013 (Scholtens 2015), Tamil Nadu fishers started to push for new negotiations through a hunger strike, leading to two new dialogue meetings in 2014 (Table 2). Although these dialogues did not lead to any concrete agreement, they were strategic in the sense that they exposed the uncomfortable reality to Indian and Tamil media that Tamil Nadu trawlers were causing major harm to their "brothers" across Palk Bay. Although the REINCORPFISH consortium had played a key role in putting the possibility of a dialogue on the agenda, they had become mostly sidelined in these follow-up dialogues.
Building the Northern Province Fisher People's Alliance

Fisheries cooperatives have been considered as vital multipurpose institutions in Sri Lankan fisheries since the country's independence (Amarasinghe and Bavinck 2011). At the inception of the project, fisher leaders in the Northern Province spoke rather wistfully of their cooperatives, which had emerged relatively unscathed from the war but were now increasingly fragmented and rapidly losing influence. In early 2011, the SLFU brought together fisher representatives from northern Sri Lanka with the aim of founding a strong umbrella organization for representing their interests. This initiative was essentially a matter of revitalizing an old province-wide union that had existed until the 1990s but collapsed during the war. The participants in this meeting, although divided by political affiliation, caste, district of origin, and fishing gear, concurred, believing that such an organization would potentially increase their influence. At the end of the meeting, the newly formed Northern Province Fisher People's Alliance (henceforth "the Alliance") presented itself to the press and handed over a petition to push for the cessation of trawling to the Indian High Commission in Colombo.

During subsequent years, the Alliance, which was generally facilitated by the SLFU, held meetings that led to the formulation of a constitution and several letters and petitions to Indian and Sri Lankan authorities. Yet, its leaders were obviously dragging their feet, ignoring the SLFU's suggestion to formalize the organization and take charge, postponing meetings and canceling planned demonstrations. 
Table 2. Overview of fisher-to-fisher dialogues in the period 2004-2014.

\begin{tabular}{|c|c|c|}
\hline Date/location & Organization & Outcome \\
\hline $\begin{array}{l}\text { May } 2004 \text { Mannar } \\
\text { and Colombo }\end{array}$ & $\begin{array}{l}\text { Initiated by NGOs with government observers } \\
\text { attending }\end{array}$ & $\begin{array}{l}\text { Agreement that trawling is harmful and has eventually to be } \\
\text { stopped. Trawlers promise to avoid fishing within three nautical } \\
\text { miles from the Sri Lankan coast. }\end{array}$ \\
\hline $\begin{array}{l}\text { August } 2010 \text { Ramnad } \\
\text { and Chennai }\end{array}$ & $\begin{array}{l}\text { Initiated by REINCORPFISH with } \\
\text { encouragement from both governments. }\end{array}$ & $\begin{array}{l}\text { Trawling in Sri Lankan waters will be stopped in one year. In the } \\
\text { interim period, } 70 \text { days are stipulated when trawlers can cross } \\
\text { the border. Governments do not endorse agreement. }\end{array}$ \\
\hline March 2011 & Sri Lankan government invites fisher & Only preliminary discussions in tense environment. Were to be \\
\hline Colombo & $\begin{array}{l}\text { representatives from both countries for a } \\
\text { meeting. }\end{array}$ & followed up by a meeting in Chennai, which did not materialize. \\
\hline January 2014 & Fisheries ministries take charge, after much & Sri Lankan fishers frame the conflict as a livelihood issue. Indian \\
\hline Chennai & pressure on Tamil Nadu. & $\begin{array}{l}\text { fishers promise not to cross over for a one month period as } \\
\text { goodwill measure. }\end{array}$ \\
\hline June 2014 & Fisheries ministries take charge. & Tamil Nadu fishers ask for more time to stop trawling. Sri \\
\hline Colombo & & $\begin{array}{l}\text { Lanka fishers harden their stand and do not wish to give more } \\
\text { time to Tamil Nadu fishers. }\end{array}$ \\
\hline
\end{tabular}

There are four reasons why the Alliance was unable and unwilling to act as the mouthpiece of northern Sri Lankan fishermen. The first reason was that of political interference. The Alliance was built on the institutional logic of the fisheries cooperative system and had drawn its institutional membership from the Fisheries Cooperative Unions of the Northern Province. Yet in this postwar period, the cooperative societies were increasingly undermined (see Scholtens 2016b). Thus, the Ministry of Fisheries, for reasons of its own, set up a new fisher organization in parallel with the cooperatives: the Rural Fisheries Organizations. The leaders of these new organizations enjoyed patronage from the Fisheries Ministry and effectively pushed the cooperative fisher leaders aside. The parallel organizational structures that thus came about created considerable friction and divisions within the fisher leadership. In addition, local politicians directly interfered in the 2012 elections of the Fisheries Cooperative Unions in the Northern Province, ensuring that their own men attained office. Arguing that this new group of cooperative officers rose only through political patronage, the Alliance leadership refused to include them in their organization. This act furthered the Alliance's oppositional identity while simultaneously reducing its linkage with the cooperative system.

The second reason was an emerging leadership crisis. The elderly fisher leader who initially assumed the chair position and enjoyed wide respect had passed away, leaving disagreements about who might replace him. The men who took over lacked the legitimacy of the erstwhile president, with fishers cynically remarking that the Alliance's primary reason of existence was to provide leadership positions to those who had just lost their positions in the cooperative elections. Thus, in Alliance meetings, most attention was devoted to contentious internal matters, such as local gear conflicts, local trawler operations, and privileges of fishers from southern Sri Lanka. In addition, in reflection of previous tensions, fisher leaders from Mannar District argued that the leadership from Jaffna District was arrogant and too frequently operated single-handedly. The leadership crisis reached its climax in mid-2014 when the Alliance's president was allegedly forced by the authorities to publicly speak out against plans for a major demonstration in Jaffna that would involve fisher groups from the entire country.
The third issue was the marginalization of the SLFU itself. In the face of a regime that is intensely suspicious of NGOs and collective action, and in possession of a ubiquitous military and intelligence apparatus to instill fear, both the Alliance and the SLFU had limited maneuvering space. Fishers were well aware that organizations like the SLFU, especially when it was operating in the north, were closely monitored by the Central Intelligence Directorate and that any protest against the government would be easily framed as a Western conspiracy (e.g., BBC Sinhala 2012). Thus, the SLFU repeatedly urged the Alliance to assert itself, hold demonstrations and demand attention for the northern fishers' situation. Fisher leaders would typically nod in response and sometimes plan demonstrations, but these were then called off a few days in advance. Rumors were also spread through the newspapers that the SLFU was using the northern fishers as pawns for the purpose of securing donor funding. The SLFU's precarious position in the country peaked in February 2012 when the government was quick to accuse the SLFU of organizing a protest against a fuel hike, which eventually forced the SLFU's director to flee the country. For fisher leaders, this situation created difficult dilemmas, as is brought out in the following statement:

We have to achieve our goals not through opposition but by going with the politics. But we need something strong to hold on [to] and to climb up. Some army commander or whatever, it has to be a Sinhalese. We don't want to oppose anyone; we just want our problem solved. We have to reach out to the government. Going against the government is useless, that is the position of our country now, especially here in the north. This is the problem with [the SLFU's] approach. ... The thing is that their approach works very well in the south and they are doing very important work, but this way doesn't work in the north. When we go to jail, nobody will look after us. Here, there is no use of demonstrating against the government. That's why we didn't want to do any of those demonstrations suggested by them. But we also need the SLFU. They are important to get the different [northern] districts together. ... We are also just tired of going against the government. We have tried it with arms for 30 years. (Fisher leader from Jaffna District, 10 Nov. 2012) 
Fourth, there was the problem of the SLFU's broader agenda. Rather than confining itself to the issue of Indian trawler intrusion, the SLFU aimed to take on a wider range of issues faced by northern fishers. This agenda meant that the SLFU also mobilized around politically sensitive issues of concern to fishers such as land dispossessions, "High Security Zones," the plight of internally displaced persons, and the military patronage of Sinhala migrant fishers. This multi-issue based approach created strategic difficulties. For instance, when building momentum against Indian trawlers, one inevitably requires support from the Sri Lankan government. Yet, mobilizing around issues related to militarization and citizenship implies confrontation with the Sri Lankan government and is typically considered as requiring Indian support. The politics of navigating alliances and opponents, as came out in the multiplicity of the SLFU's agenda, created further internal strife and demobilization among the fisher leadership. In sum, the combination of political interference, militarization, internal strife, suspicion, and the lack of single focus around which to build a movement made it virtually impossible for the Alliance to flourish.

\section{Achieving government buy-in}

The consortium, taking the side of the northern Sri Lankan fishers and confronting the Indian trawl fishers without focusing on ethnic discrimination or human rights discourses that have dominated most international involvement in Sri Lanka, initially assumed that collaboration with the Sri Lankan state would be relatively easy. However, this assumption soon proved to be incorrect for reasons that have already been touched upon. The political sensitivity of the project was already apparent during the preparations for the first project workshop, which was hosted by the University of Jaffna in January 2011. Indications were a police inquiry into possible LTTE-connections of the Sinhala academic representing the University of Ruhuna and a letter from the Sri Lankan High Commission in New Delhi pointing out the risks of having Indian participants present.

Despite many efforts from the project side and the Netherlands embassy to introduce the project coordinator to the Minister of Fisheries and, in the words of a high Dutch official, "overcome the anxieties generally caused by this kind of project," such a meeting was never realized. Instead, tensions increased after the SLFU director, having received undefined threats to his life, fled the country and the Netherlands Organization for Scientific Research (NWO) requested the Minister of Fisheries to ensure his safety. The academic representing the University of Ruhuna was subsequently blacklisted, and Ministry officials were denied permission by their superiors to attend the two conferences that were initiated by the project on the Palk Bay fishing conflict. As a result, almost no interaction came about between the government and the project at an official level. The reasons for this condition are complex and still partly obscure. Several external factors seem to have played an important role, however, including (1) The postwar government's antagonism toward Western interference in its affairs, fed by events at the UNHRC council meetings in Geneva; (2) the postwar government's antipathy toward all NGO activity and the fisheries Minister's personal dislike of the SLFU; and (3) fear of a resurrection of Tamil guerrilla activity and suspicion of all project activities in the Northern Province, particularly if the activities had an Indian component. These factors were largely external to the project's strategy, as is suggested by the fact that they partly dissipated with the change of government in 2015 (which is beyond the scope of this paper). The difficulties faced, however, resulted in a revision of the project's strategy, placing more emphasis on advocacy.

\section{Advocating fisher rights}

To create awareness for the plight of northern Sri Lankan fishers among a broader Sri Lankan audience, both the universities and the SLFU tried to organize workshops and seminars in the north and the south of the country and to inform and engage Sri Lankan and Indian media. The hope was that such pressure would encourage the Sri Lankan government to act more assertively toward India on the fisheries issue, which otherwise figured too easily as a pawn in bilateral negotiations.

The advocacy program sought to reveal the injustices experienced by northern Sri Lankan fishers, which required confronting a powerful set of dominant discourses. These included the following: (1) In Tamil Nadu, trawl fishers are seen as the main victims in the conflict because of their arrests by the Sri Lankan Navy; (2) From a Sinhalese nationalist perspective, the main problem is a patronizing India interfering in national affairs and breaching its sovereignty; and (3) From a Sri Lankan Tamil nationalist perspective, any challenge to the Tamil people is the result of oppression by the Sri Lankan government.

The anxieties surrounding the organizing of a national advocacy workshop on the trawl issue at the northern university illustrate the power of these discourses. First, as a local professor argued in March 2012, the upcoming UNHRC voting round ensured that Sri Lanka was in the international spotlight; the northern university should, therefore, be reluctant to provide the government any opportunity to internationally show off in a "reconciliatory" light. Second, the professor argued that the university staff would also likely be suspicious of such a northsouth bridging workshop, as speaking out against trawlers would imply confronting Tamil Nadu, which was found unacceptable in the days close to the UNHRC voting; the Tamils on both sides of the Palk Bay rather had to form a single front. Third, the internal division among fisher leaders posed dilemmas. Not only was it impossible to get all of the relevant leaders to a meeting of this kind, internal disagreements that might be voiced before government officials would cause unwanted embarrassment. Fourth, it was feared that the meeting would attract attention from intelligence agencies and government-affiliated politicians, effectively securitizing the meeting and potentially bringing the military to the university campus. Fifth, fishers felt that the castebased arrogance of most university staff, or any other elite, for that matter, toward fishers made it unlikely that such a meeting bore any real relevance for them.

Hence, fisher leaders, clergy, and university staff all hesitated to endorse such an advocacy meeting, not only knowing that one misstep could compromise their positions or lead to some form of retaliation but also feeling that chances for success were limited. This attitude may also be associated with a larger postwar socialpsychological lethargy in Jaffna (Somasundaram and Sivayokan 2013).

Meanwhile, the SLFU, aiming to build a national fisher movement, organized meetings throughout Sri Lanka, providing fishers from various parts of the country a platform for speaking 
Table 3. Project activities and obstacles faced.

\begin{tabular}{|c|c|c|c|}
\hline & Element of bottom-up governance & Element of empowerment & Obstacles \\
\hline Transboundary Dialogues & $\begin{array}{l}\text { Start with fishers in proposing rules } \\
\text { and norms. }\end{array}$ & $\begin{array}{l}\text { Negotiating collective outcomes, } \\
\text { building linking capital }\end{array}$ & $\begin{array}{l}\text { Suspicion by Sri Lankan } \\
\text { government; } \\
\text { Governments' unwillingness to back } \\
\text { up; } \\
\text { Tamil Nadu fishers' lobby too } \\
\text { powerful; } \\
\text { Entanglement in bilateral politics. }\end{array}$ \\
\hline Alliance building & $\begin{array}{l}\text { Build institutional capacity for } \\
\text { fishers as precondition for self- and/ } \\
\text { or comanagement. }\end{array}$ & $\begin{array}{l}\text { Creating a shared vocabulary, } \\
\text { asserting rights, and associating for } \\
\text { public action. }\end{array}$ & $\begin{array}{l}\text { Internal frictions on strategy; } \\
\text { Political interference and inability to } \\
\text { align with patronage networks; } \\
\text { Postwar suppression of } \\
\text { mobilization; } \\
\text { SLFU repression. }\end{array}$ \\
\hline Government buy-in & $\begin{array}{l}\text { Achieve recognition of the } \\
\text { problems' urgency and the need to } \\
\text { involve fishers in a solution. }\end{array}$ & $\begin{array}{l}\text { Striving to bring the Alliance into } \\
\text { the negotiating process }\end{array}$ & $\begin{array}{l}\text { Unwillingness of the Sri Lankan } \\
\text { government to engage with NGOs; } \\
\text { Suspicion toward project's motives; } \\
\text { Negative path dependency. }\end{array}$ \\
\hline Advocacy & Support fishers in voicing concerns. & $\begin{array}{l}\text { Challenging discourses and } \\
\text { mobilizing support. }\end{array}$ & $\begin{array}{l}\text { Unbridgeable ethnic divide; } \\
\text { Lack of political space for } \\
\text { engagement; } \\
\text { Resistance from Tamil nationalist } \\
\text { agendas. }\end{array}$ \\
\hline
\end{tabular}

out. Although in the north these meetings were always surrounded by security tensions, organizing meetings in Colombo proved more feasible. In February 2013, the SLFU organized a large meeting for fishers in Colombo, also attended by academics from various universities, politicians, and clergy. Later, with the buy-in from five Sri Lankan universities, the consortium organized a Palk Bay fisheries conference in the capital in 2014, providing renewed momentum. These meetings were arguably significant in terms of sensitizing new audiences to the fisheries struggle and enticed journalists to dive into and report on the livelihood challenges faced by northern Sri Lankan fishers. Press coverage on northern fisheries considerably increased over time, both in quality and quantity.

Finally, a major advocacy challenge was to break the silence of the Tamil elite, in particular, the Northern Provincial Council and the TNA. One TNA politician remarked:

\section{Though New Delhi has been committed to our cause, we need Jayalalitha [Chief Minister Tamil Nadu] to pressurize New Delhi periodically. We know that the Tamil Nadu fishers are at fault, but we cannot afford to antagonize Tamil Nadu, which has backed us for so long. (Srinivasan 2014:3)}

Many fishers privately complained about the elitist nature of the TNA, yet felt that a full-fledged advocacy to embarrass the TNA was not desired in order to keep up the appearance of a united Tamil front against Colombo.

\section{Reincorporating the excluded?}

Although this article is not intended as a project evaluation, we cannot avoid the question of whether the consortium succeeded in helping northern Sri Lankan fishers improve their access to fish resources. Convincing outcomes are limited because, by the end of the project in 2016, Tamil Nadu trawl fishers still had a relatively free run in Sri Lankan waters. Table 3 summarizes the various strategies employed by the project and the various obstacles it confronted.

Despite these obstacles and setbacks, between 2010 and 2016, a major shift occurred in the public discourse regarding the Palk Bay fisheries conflict, both in India and Sri Lanka. At the inception of the project in 2010, the Palk Bay fisheries issue in India was predominantly framed as the Sri Lankan Navy harassing Tamil Nadu fishers, so the Sri Lankan government was largely forced into a defensive position; northern Sri Lankan fishers figured nowhere in the discussion. In 2013, both the vernacular and English media in Sri Lanka and India were increasingly giving attention to the negative impacts of trawling on northern Sri Lankan fishers, and governmental authorities in the Northern Province and in Sri Lanka's capital had become more assertive about northern fishers' rights. By 2016, the negative impacts of trawlers were reluctantly acknowledged in India, and the governments of both Tamil Nadu and India had started to actually investigate options for restructuring the trawl fleet. Although attribution problems are obvious, the final, external project evaluation report concluded that the project likely made important contributions to these developments (H. Dijkhorst 2016, unpublished report).

\section{DISCUSSION}

\section{Conflict transformation from the bottom up?}

We commenced by discussing the rationale for addressing conflicts over access to natural resources through bottom-up governance, which informed the REINCORPFISH project. The notion of bottom-up governance emphasizes the importance of creating ownership, participation, and collaboration and suggests that, without engagement from fisher organizations, there can neither be a fair and effective governance solution nor can fisher conflicts be resolved. 
In the authoritarian context of postwar Sri Lanka, several challenges emerged from this approach. First, bottom-up governance suggests that user groups and civil society can act as initiators of change, with the state being at the receiving end. In our case study, this normative notion was defied by evidence of an extremely assertive government that was unreceptive, if not outright antagonistic, to civic agency. Although fishing practices of nearshore fisheries typically attract little governmental attention, in the transnational setting of the Palk Bay, fisheries were closely entangled with the Sri Lankan state's concerns of security and sovereignty. These concerns also made the government reluctant to endorse a form of track II diplomacy.

Second, the postwar context and prevailing ethnic tensions ensured strong state control over any activity in northern Sri Lanka. Although the international members of the consortium had expected a certain level of power politics, they had not anticipated such intense levels of suspicion and political interference. In the prevailing context, there was very little space for bottom-up engagement unless it was conducted under the patronage of cabinet-level politicians, military, or other authorities, rendering notions of collaborative interaction and participation rather elusive. In arriving at this conclusion, we do not wish to suggest, however, that bottom-up governance is, in general, an inoperable strategy, and neither does it disprove the assumption that effective governance starts with fisher involvement. However, these normative predispositions are of little help to understand why such ideals are so difficult to accomplish in practice.

\section{Empowerment: between collaboration and confrontation}

Our conceptual discussion highlighted two contrasting approaches to empowerment. In the context of REINCORPFISH, controversy manifested itself both in terms of how and in relation to whom fishers were supposed to be empowered. For the SLFU, the project's goals implied the creation of a social movement of fishers who would fight for their legitimate rights. With both Indian trawlers and the government compromising these rights, this approach implied confrontations with Indian fishers, their political supporters, and the Sri Lankan authorities. For others, however, the project meant engaging fishers in creating a step-bystep collaborative negotiation process both with Indian fishers and the Sri Lankan authorities.

Some project partners and fisher leaders were of the opinion that the SLFU's confrontational approach was counterproductive. The fisher leader's statement mentioned above illustrates that bottom-up processes of empowerment can expose or deepen existing vulnerabilities. Under authoritarian conditions, NGOs are often not in the position to protect their "subjects" when the going gets rough, leading to potentially risky situations. As a result of the government's outright suppression of the SLFU, not only did the Alliance become marginalized, but also university partners' access to state officials also became blocked, thus impeding a more negotiated approach.

In terms of a constructive approach, however, it proved impossible to simultaneously create a dialogue with the Sri Lankan government and the trawl fishers from Tamil Nadu: The project's efforts to facilitate bilateral fisher dialogues were, after all, met with the greatest suspicion by the Sri Lankan government. Although an approach of working constructively with all parties toward a negotiated solution may have been sensible from the logic of a multistakeholder deliberation, in the context of domestic ethnic tension and geopolitical swagger, any form of empowerment of one actor with regard to another could only end in a political hornet's nest.

As it turned out, the REINCORPFISH interventions also drew flak from other, critical quarters in Sri Lanka. By 2015, a network of activists had emerged that criticized the project for taking too mild of an approach, i.e., dialogue, to the poaching Tamil Nadu trawl population, for not making more use of available legal options in Sri Lanka, and for its reluctance to frame trawler intrusions as an act of Illegal Unregulated and Unreported (IUU) fishing, thereby inviting international pressure. Whether these critiques hold true is irrelevant for this paper; the point we are aiming to make here is that by 2015 , different parties proved to have different ideas of who had to be empowered against whom, for what purpose, and by what means.

The tensions that emerge from theory between transformative confrontational and revisionist approaches have thus been apparent in practice. In particular, simultaneously employing both approaches may work in mutually reinforcing ways but can also create notable frictions. The action research approach also made the theoretically useful dichotomy less clear-cut: efforts to carefully facilitate interaction between stakeholders did bring about some change, yet these changes were suddenly politicized and lost in suspicion; efforts to mobilize fishers in demonstrations were repressed at first, yet suddenly, interaction opened doors for negotiations and brought about a shift in problem framings.

\section{Civil society as an agent of change?}

REINCORPFISH framed the conflict as an asymmetrical struggle requiring a transformation process via bottom-up governance, with civil society playing an important role as an agent of change. The above discussion suggests that there were two problems with this approach. The first issue relates to treating civil society as a singular actor rather than as comprising diverse actors and organizations with different and potentially competing interests and accountabilities. Fishing communities in northern Sri Lanka were too divided to represent a "unified fisher interest," and politicians, NGOs, concerned individuals, and academics each claimed to represent the northern fishers in their own way. Second, the project framing assumed that scientists and activists would be able to perform the role of change agent to help fisher communities in voicing and addressing their concerns. The prevailing situation in Sri Lanka, however, offered extremely little space for civil society to operate. The position of civil society visà-vis the Sri Lankan state was heavily restricted, and the opportunities to operate were too limited to assist fishers vis-àvis the Tamil Nadu trawl fishers and the Sri Lankan state. The entrenchment of the fisheries conflict in bilateral and ethnic politics and the suspicions of both governments toward thirdparty mediation in what was viewed as an internal dispute further marginalized the role of civil society actors. What our case demonstrates is that neither can space for bottom-up processes be assumed nor can the role of civil society as an agent of change.

Although this observation could easily result in cynicism, a sense of proportion is in place here. Since the two governments in question were clearly unable or unwilling to address the injustice prevailing in the Palk Bay, the project represented a strong effort 
to construct a collective intentionality among as many actors as possible. Despite mounting obstacles, the regular collaboration between academics, fisher leaders, clergy, journalists, and NGOs succeeded in putting the injustice suffered by northern fishers on the national public and political agenda. What the consortium may have underestimated, however, were the level of internal divisions and politics among Sri Lankan fishers and the sheer reluctance of Tamil and Sinhalese elites to confront India on the issue of transboundary fishing.

Finally, the framing of the project as a fisheries conflict implied a sectoral approach, which assumed that problems could be tackled within the domain of fisheries. This perspective was, on the one hand, logical, because the transboundary conflict was clearly about fishing rights. On the other hand, it arguably failed to foreground how northern Sri Lankan fishers' marginality resulted not only from poaching Indian trawlers but also from a broader set of relations beyond the fisheries sector. Fishers possess multiple identities, including caste, ethnicity, and nationality, each of which produces its own marginalities that cannot easily be understood through a sectoral approach. A sectoral approach, in other words, is in danger of isolating an issue from its wider contexts, ignoring the intersection of structural conditions that create marginality at various levels ( $\mathrm{Li}$ 2007).

\section{CONCLUSIONS}

We have analyzed the efforts of a project to facilitate bottom-up governance to transform a transboundary fisheries conflict in a postwar setting, and identified a range of factors affecting the potential for such transformation. The "transboundary" and "postwar" qualifications are vital in order to understand the challenges that were encountered. Transboundary resource conflicts involve two or more governments, two navies, multiple courts and ministries, and entangle fisheries with nationalist anxieties of security, sovereignty, and geopolitical power play. In the context of the REINCORPFISH project, these entanglements implied that project dynamics in Sri Lanka greatly depended upon political developments in Tamil Nadu and India and vice versa. The powerful political support enjoyed by the trawl fishers in Tamil Nadu impeded efforts to identify potentially effective paths of engagement in Sri Lanka. In addition, the political backlash against the project in Sri Lanka partly resulted from the consortium's efforts to simultaneously work in two countries.

The fact that REINCORPFISH was immediately initiated after the civil war ended also played a decisive role. The Sri Lankan state was in a victorious and militaristic frame of mind, suspicious of any internal dissent and international involvement, and the Tamil fishing population in the north was too vulnerable for collective mobilization. Postwar interventions aimed at revitalizing marginal livelihoods, especially in authoritarian contexts, thus face a double problem: constructive efforts of institutional capacity building might be distrusted for undermining the state, while efforts at mobilizing communities to challenge governmental authorities run the risk of strong repression.

This particular postwar, authoritarian, and transboundary context arguably makes for an extreme case study, which does not automatically allow for generalizing. Yet, such an extreme case study can be particularly useful to expose limitations to concepts like bottom-up governance, which may not be easily revealed in more moderate contexts. For bottom-up engagement to work, political space is required, whether invited by the state, claimed by citizens through collective protest, or negotiated between the two parties (Baud and Nainan 2008). In the absence of such political space, actors can easily be turned against one another, community leadership can be neutralized and civil society can be squeezed. Interventions inspired by liberal notions of empowerment, comanagement, and multistakeholder deliberation may too readily assume that political space for bottom-up engagement is available, thereby endangering not only their own efforts but also the lives of the people they are actually aiming to serve.

The action research underlying this article entails an engaging self-reflection, positioning ourselves both inside and outside the intervention and thereby acting simultaneously as both subject and object of research. Through the simultaneous practice of research and action, action research allows for developing an understanding not only through research but also through action itself. In our case, transforming a fisheries conflict through action research meant working through the multiplicity of coexisting tensions (resource, ethnic, and geopolitical) that are frequently studied in isolation. The notion that conflicts have multiple dimensions challenges the inclination to work from a sectoral perspective: a transformative agenda does not allow fisheries conflicts to be separated from conflicts about ethnicity, caste, and geopolitics. In action research, reducing reality's messiness and complexity can, thus, boomerang quite easily (Mathews 2011). Yet paradoxically, acknowledging this entanglement of fisheries conflicts with historically laden ethnic and geopolitical anxieties also makes conflicts less intervenable.

The final, overarching question to be raised is how critical analysis can be combined with genuine efforts of transdisciplinary consortia to transform conflicts for the benefit of marginal groups. The rationale for such action is provided by Flyvbjerg's (2001) inquiry on "making social science matter" for which he and others propose focusing on "tension points" (Flyvbjerg et al. 2012). This implies that social scientists should study issues in which power relations "are particularly susceptible to problematization and thus to change, because they are fraught with dubious practices, contestable knowledge and potential conflict. Thus, even a small challenge - like problematization from scholars - may tip the scales and trigger change in a tension point" (Flyvbjerg et al. 2012:288). We hope that the REINCORPFISH project, despite its evident weaknesses, may have played a role of this kind.

Responses to this article can be read online at: http://www.ecologyandsociety.org/issues/responses. php/10216

\footnotetext{
Acknowledgments:

We wish to thank all partners of the REINCORPFISH project and the Dutch research programme COCOON (NWO/WOTRO project W076830200) for funding this research.
} 


\section{LITERATURE CITED}

Amarasinghe, O., and M. Bavinck. 2011. Building resilience: fisheries cooperatives in Southern Sri Lanka. Pages 383-406 in S. Jentoft and A. Eide, editors. Poverty mosaics: realities and prospects in small-scale fisheries. Springer, Dordrecht, The Netherlands. http://dx.doi.org/10.1007/978-94-007-1582-0_17

Armitage, D. 2007. Governance and the commons in a multi-level world. International Journal of the Commons 2(1):7-32. http://dx. doi.org/10.18352/ijc. 28

Baud, I., and N. Nainan. 2008. "Negotiated spaces" for representation in Mumbai: ward committees, advanced locality management and the politics of middle-class activism. Environment and Urbanization 20:483-499. http://dx.doi. org/10.1177/0956247808096124

Bavinck, M. 2001. Marine resource management: conflict and regulation in the fisheries of the Coromandel Coast. Sage, New Delhi, India.

Bavinck, M. 2005. Understanding fisheries conflicts in the south - a legal pluralist perspective. Society \& Natural Resources 18 (9):805-820. http://dx.doi.org/10.1080/08941920500205491

BBC Sinhala. 2012. Protest against 'Western Conspiracy.' $B B C$ Sinhala, 23 February. [online] URL: http://www.bbc.com/sinhala/ news/story/2012/02/120223 west conspiracy.shtml

Chandrahasan, N. 2014. Maritime boundaries in the Indian Ocean: Sri Lanka and the law of the sea. Stamford Lake, Pannipitiya, Sri Lanka.

Christie, P., and A. T. White. 2007. Best practices for improved governance of coral reef marine protected areas. Coral Reefs 26 (4):1047-1056. http://dx.doi.org/10.1007/s00338-007-0235-9

Chuenpagdee, R., and S. Jentoft. 2009. Governability assessment for fisheries and coastal systems: a reality check. Human Ecology 37(1):109-120. http://dx.doi.org/10.1007/s10745-008-9212-3

David, K. 2013. Modalities of an emergent dictatorship. Economic and Political Weekly 48(7):30-33.

Davis, A., and K. Ruddle. 2012. Massaging the misery: recent approaches to fisheries governance and the betrayal of small-scale fisheries. Human Organization 71(3):244-254. http://dx.doi. org/10.17730/humo.71.3.205788362x751128

Flyvbjerg, B. 2001. Making social science matter: why social inquiry fails and how it can succeed again. Cambridge University Press, Cambridge, UK. http://dx.doi.org/10.1017/CBO9780511810503

Flyvbjerg, B., T. Landman, and S. Schram. 2012. Real social science. Cambridge University Press, Cambridge, UK. http://dx. doi.org/10.1017/CBO9780511719912

Fowler, A., and K. Biekart. 2013. Relocating civil society in a politics of civic-driven change. Development Policy Review 31 (4):463-483. http://dx.doi.org/10.1111/dpr.12015

Frerks, G., T. Dietz, and P. van der Zaag. 2014. Conflict and cooperation on natural resources: justifying the $\mathrm{CoCooN}$ programme. Pages 13-34 in M. Bavinck, L. Pelligrini, and E. Mosterd, editors. Conflicts over natural resources in the Global South: conceptual approaches. CRC, Boca Raton, Florida, USA.
Friedmann, J. 1992. Empowerment, the politics of alternative development. Blackwell, Oxford, UK.

Gray, T. S. 2005. Participation in fisheries governance. Springer, Dordrecht, The Netherlands. http://dx.doi.org/10.1007/1-4020-3778-3

Hoole, E., and S. Arulingam. 2015. Beyond Tamil nationalism. Samakalam, 01 August.

Jentoft, S. 1989. Fisheries co-management: delegating government responsibility to fishermen's organizations. Marine Policy 13(2):137-154. http://dx.doi.org/10.1016/0308-597X(89) 90004-3

Jentoft, S. 2004. The community in fisheries management: challenges, opportunities and risks. Page 93-129. in B. Hersoug, S. Jentoft, and P. Degnbol, editors. Fisheries development: the institutional challenge. Eburon, Delft, The Netherlands.

Jentoft, S. 2005. Fisheries co-management as empowerment. Marine Policy 29(1):1-7. http://dx.doi.org/10.1016/j.marpol.2004.01.003

Jentoft, S. 2007. In the power of power: the understated aspect of fisheries and coastal management. Human Organization 66 (4):426-437. http://dx.doi.org/10.17730/humo.66.4.a836621h2k5x46m2

Kadirgamar, A. 2013. The question of militarisation in post-war Sri Lanka. Economic Political Weekly XLVIII(No 7):42-46.

Kelleher, A., and J. L. Taulbee. 2017. Building peace Norwegian style: studies in track I1/2 diplomacy. Pages 69-84 in H. F. Carey, editor. Subcontracting peace: the challenges of NGO peacebuilding. Routledge, London, UK.

Kooiman, J., and M. Bavinck. 2005. The governance perspective. Pages 11-24 in J. Kooiman, M. Bavinck, S. Jentolft, and R. Pullin, editors. Fish for life: interactive governance for fisheries. Amsterdam University Press, Amsterdam, The Netherlands. http://dx.doi.org/10.5117/9789053566862

Kooiman, J., S. Jentoft, R. Pullin, and M. Bavinck, editors. 2005. Fish for life: interactive governance of fisheries and aquaculture. Amsterdam University Press, Amsterdam, The Netherlands. http://dx.doi.org/10.5117/9789053566862

Kuganathan, P. 2014. Social stratification in Jaffna: a survey of recent research on caste. Sociology Compass 8(1):78-88. http://dx. doi.org/10.1111/soc4.12101

Kumar, S. 2013. The military expansion into education. Economic and Political Weekly XLVIII(7).

Li, T. M. 2007. The will to improve: governmentality, development, and the practice of politics. Duke University Press, Durham, North Carolina, USA. http://dx.doi.org/10.1215/9780822389781

Loveman, M. 1998. High-risk collective action: defending human rights in Chile, Uruguay, and Argentina. American Journal of Sociology 104(2):477-525. http://dx.doi.org/10.1086/210045

Lund, C. 2010. Approaching development: an opinionated review. Progress in Development Studies 10(1):19-34. http://dx.doi. org/10.1177/146499340901000102

Mathews, A. S. 2011. Instituting nature: authority, expertise, and power in Mexican forests. MIT Press, Cambridge, Massachusetts, USA. http://dx.doi.org/10.7551/mitpress/9780262016520.001.0001 
Menon, A., M. Bavinck, and J. Stephen. 2016. The political ecology of Palk Bay fisheries: geographies of capital, fisher conflict, ethnicity and nation-state. Antipode 48(2):393-411. http://dx.doi.org/10.1111/anti.12181

Ministry of Fisheries and Aquatic Resources Development (MFARD). 2015. Fisheries Statistics 2015. MFARD, Colombo, Sri Lanka.

Mohan, G., and K. Stokke. 2000. Participatory development and empowerment: the dangers of localism. Third World Quarterly 21 (2):247-268. http://dx.doi.org/10.1080/01436590050004346

Mwangi, E. and A. Wardell. 2012. Multi-level governance of forest resources. International Journal of the Commons 6 (2):79-103. http://dx.doi.org/10.18352/ijc.374

Ostrom, E. 1990. Governing the commons: the evolution of institutions for collective action. Cambridge University Press, Cambridge, UK. http://dx.doi.org/10.1017/CBO9780511807763

Paris R. 2004. At war's end: building peace after civil conflict. Cambridge University Press, Cambridge, UK. http://dx.doi. org/10.1017/CBO9780511790836

Pomeroy, R. S., and F. Berkes. 1997. Two to tango: the role of government in fisheries co-management. Marine Policy 21 (5):465-480. http://dx.doi.org/10.1016/S0308-597X(97)00017-1

Ribot, J. C., and N. L. Peluso. 2003. A theory of access. Rural Sociology 68(2):153-181. http://dx.doi.org/10.1111/j.1549-0831.2003. tb00133.x

Rosenau, J. N., and E.-O. Czempiel. 1992. Governance without government: order and change in world politics. Cambridge University Press, Cambridge, UK. http://dx.doi.org/10.1017/ $\underline{\text { CBO9780511521775 }}$

Sathiya Moorthy, N. 2013. Sri Lanka: fishing for a solution in the Palk Bay. Observer Research Foundation, 12 April. [online] URL: https://www.orfonline.org/research/sri-lanka-fishing-for-a-solutionin-the-palk-bay/

Scholtens, J. 2015. Limits to the governability of transboundary fisheries: implications for small- scale fishers in northern Sri Lanka and beyond. Pages 515-536 in S. Jentoft and R. Chuenpagdee, editors. Interactive governance for small-scale fisheries: global reflections. Springer, Dordrecht, The Netherlands. http://dx.doi.org/10.1007/978-3-319-17034-3 27

Scholtens, J. 2016a. Fishing in the margins. North Sri Lankan fisher's struggle for access in transboundary waters. Dissertation. University of Amsterdam, Amsterdam, The Netherlands.

Scholtens J. 2016b. The elusive quest for access and collective action: north Sri Lankan fishers' thwarted struggles against a foreign trawler fleet. International Journal of the Commons 10 (2):929-952. http://dx.doi.org/10.18352/ijc.627

Scholtens, J., and M. Bavinck. 2014. Lessons for legal pluralism: investigating the challenges of transboundary fisheries governance. Current Opinion in Environmental Sustainability 11:10-18. http://dx.doi.org/10.1016/j.cosust.2014.09.017

Scholtens, J., M. Bavinck, M., and A. S. Soosai. 2012. Fishing in dire straits: trans-boundary incursions in the Palk Bay. Economic and Political Weekly 87-95.
Scholtens, J., J. Stephen, and A. Menon. 2013. Between the devil and the not-so-deep blue sea: asymmetrical power in the Indo-Sri Lankan fisheries conflict. Broker Online, 6 November.

Somasundaram, D., and S. Sivayokan. 2013. Rebuilding community resilience in a post-war context: developing insight and recommendations - a qualitative study in northern Sri Lanka. International Journal of Mental Health Systems 7(3):1-24. http:// dx.doi.org/10.1186/1752-4458-7-3

Sowman, M., and R. Wynberg. 2014. Governance, equity and sustainability in sub-saharan africa: an introduction to the discourse. Pages 1-368 in M. Sowman and R. Wynberg, editors. Governance for justice and environmental sustainability. Routledge, New York, USA.

Srinivasan, M. 2014. Double disadvantage. Frontline, 11 July.

Stephen, J. 2015. Fishing for space: socio-spatial relations of Indian trawl fishers in the Palk Bay, South Asia, in the context of transboundary fishing. Dissertation. University of Amsterdam, Amsterdam, The Netherlands.

Stephen, J., A. Menon, J. Scholtens, and M. Bavinck. 2013. Transboundary dialogues and the 'politics of scale' in Palk Bay fisheries: brothers at sea? South Asia Research 33(2):141-161. http://dx.doi.org/10.1177/0262728013487633

Suryanarayan, V. 2005. Conflict over fisheries in the Palk Bay region. Lancer, New Delhi, India.

Torfing, J., B. G. Peters, J. Pierre, and E. Sørensen. 2012. Interactive governance: advancing the paradigm. Oxford University Press, New York, New York, USA. http://dx.doi. org/10.1093/acprof:oso/9780199596751.001.0001

van Ginkel, R. 2009. Braving troubled waters: sea change in a Dutch fishing community. Amsterdam University Press, Amsterdam, The Netherlands.

Veltmeyer, H. 2009. Civil society and development. Pages 211-228 in P. A. Haslam, P. Beaudet, and J. Shafer, editors. Introduction to international development: approaches, actors, and issues. Oxford University Press, Oxford, UK.

Wickramasinghe, N. 2014. Sri Lanka in the modern age; a history. Hurst and Company, London, UK. 